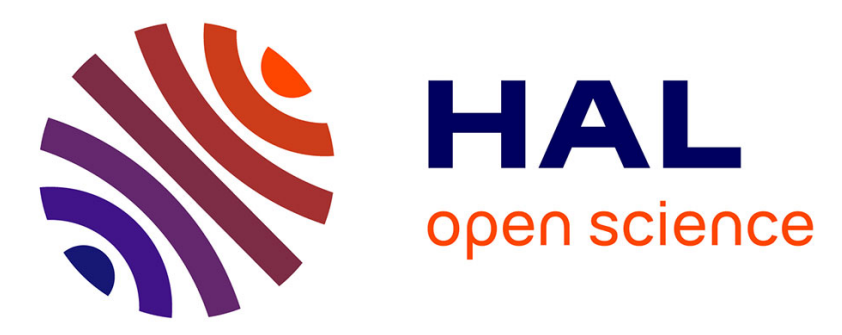

\title{
Effect of confining pressure on the strength of wet quartzite revisited
}

Lucille Nègre, Holger Stünitz, Hugues Raimbourg, Jacques Précigout, Petr Jeřábek, Petar Pongrac

\section{To cite this version:}

Lucille Nègre, Holger Stünitz, Hugues Raimbourg, Jacques Précigout, Petr Jeřábek, et al.. Effect of confining pressure on the strength of wet quartzite revisited. EGU General Assembly 2020, May 2020, Online, France. 10.5194/egusphere-egu2020-5595 . hal-03554435

\section{HAL Id: hal-03554435 \\ https://hal.science/hal-03554435}

Submitted on 3 Feb 2022

HAL is a multi-disciplinary open access archive for the deposit and dissemination of scientific research documents, whether they are published or not. The documents may come from teaching and research institutions in France or abroad, or from public or private research centers.
L'archive ouverte pluridisciplinaire HAL, est destinée au dépôt et à la diffusion de documents scientifiques de niveau recherche, publiés ou non, émanant des établissements d'enseignement et de recherche français ou étrangers, des laboratoires publics ou privés.

\section{(c)(1)}

Distributed under a Creative Commons Attribution| 4.0 International License 
EGU2020-5595, updated on 03 Feb 2022

https://doi.org/10.5194/egusphere-egu2020-5595

EGU General Assembly 2020

(c) Author(s) 2022. This work is distributed under

the Creative Commons Attribution 4.0 License.

\section{Effect of confining pressure on the strength of wet quartzite revisited}

Lucille Nègre ${ }^{1}$, Holger Stünitz ${ }^{1,2}$, Hugues Raimbourg ${ }^{1}$, Jacques Précigout ${ }^{1}$, Petr Jeřábek ${ }^{3}$, and Petar Pongrac ${ }^{3}$

'Institut des Sciences de la Terre d'Orléans (ISTO), Université d'Orléans, CNRS, BRGM, UMR 7327, Orléans, France

(lucille.negre@univ-orleans.fr)

${ }^{2}$ Department of Geosciences, The Arctic University of Norway, Tromsø, Norway

${ }^{3}$ Institute of Petrology and Structural Geology, Charles University, Prague, Czech Republic

The ability of water to enhance plastic deformation of a quartz aggregate has been experimentally demonstrated during the sixties (e.g. Griggs and Blacic 1965), however the processes involved are still questioned. Notably the processes combining the effect of water and pressure during the deformation are still not completely understood. Pressure strongly influences the strength of finegrained (3.6 - $4.9 \mu \mathrm{m}$ ) wet quartz aggregates (Kronenberg and Tullis 1984), where diffusion creep operates (Fukuda et al. 2018) but its effect on coarser-grained material expected to deform only by dislocation creep is not well constrained. To re-assess the effect of pressure on quartz crystal plastic deformation, natural wet quartzite samples from the Tana quarry in northern Norway (grain size $\approx 150 \mu \mathrm{m}$ ) have been deformed using a Griggs-type apparatus at varying confining pressures (from 0.6 to $2.0 \mathrm{GPa}$ ). All the samples with $0.1 \mathrm{wt} . \% \mathrm{H}_{2} \mathrm{O}$ added were shortened coaxially up to $30 \%$ strain at constant strain rate $\left(\approx 10^{-6} \mathrm{~s}^{-1}\right)$ and temperature $\left(900^{\circ} \mathrm{C}\right)$.

All mechanical records show that quartzite flow stresses decrease systematically with increasing pressure. These results allow to determine the strength of quartzite as a function of water fugacity, such as introduced in the flow law by Kohlstedt et al. (1995) to account for both pressure and water effects. In our case, the fugacity coefficient is $m \approx 1$ when using a stress exponent of $n=2$.

Microstructure and image analyses of samples reveal that the bulk strain results mainly from crystal plastic deformation of original grains whereas the recrystallization processes are limited volumetrically (less than 5\%) and restricted to the boundaries of original grains. Deformation is not strongly partitioned into recrystallized domains compared to flattened original grains. Optical and SEM-cathodoluminescence images revealed the presence of cracks in conjunction with recrystallization (even for high-pressure samples) and associated chemical/fluid interaction, but the cracks do not contribute significantly to the bulk strain of the samples.

In order to determine the amount of water used for the deformation and the redistribution of $\mathrm{H}_{2} \mathrm{O}$ during deformation, the $\mathrm{H}_{2} \mathrm{O}$ content of the quartzite has been calculated from FTIR (Fourier Transform InfraRed spectroscopy) measurements for both, grain interiors and grain boundaries. The $\mathrm{H}_{2} \mathrm{O}$ concentrations decrease inside grains with the onset of deformation with respect to the 
starting material. $\mathrm{H}_{2} \mathrm{O}$ is primarily stored in the grain boundary region. There is no systematic correlation with pressure. Thus, pressure dependence of $\mathrm{H}_{2} \mathrm{O}$ weakening is not restricted to finegrained materials at high pressure and temperature. Deformation redistributes water from the grain interiors to their grain boundaries.

References:

Fukuda, J., Holyoke III, C.W., and Kronenberg, A.K. (2018). J. Geophysical Res.: Solid Earth, 123(6), 4676-4696.

Griggs, D. T., and Blacic J. D. (1965). Science, 147(3655), 2920295.

Kohlstedt, D. L., Evans B., and Mackwell S. J. (1995). J. Geophysical Res.: Solid Earth, 100(B9), 17587-17602.

Kronenberg, A. K., and Tullis J. (1984). J. Geophysical Res.: Solid Earth, 89(B6), 428104297. 